УДК 34.343.2

DOI https://doi.org/10.32849/2663-5313/2020.7.51

Олена Олійник,

канд. юрид. наук, дочент,

доцент кафедри кримінального права та прочесу

Київського національного економічного університету

імені Вадима Гетьмана

\title{
ХАРАКТЕРИСТИКА ЗОВНІШНІХ I ВНУТРІШНІХ ЧИННИКІВ, ЯКІ ВПЛИВАЮТЬ НА ФОРМУВАННЯ ТА СТАНОВЛЕННЯ СИСТЕМИ ПРИНЦИПІВ КРИМІНАЛЬНОГО ПРАВА
}

Статтю присвячено питанню виявлення чинників, які так чи інакше впливають на формування та становлення принципів кримінального права в аспекті становлення правової системи загалом. Авторка статті має на увазі досвід съогодення, який яскраво продемонстрував, що людство під час виникнення критичної ситуаџї, яка може загрожувати життю та здоров'ю багатьох осіб, керується своїми інстинктами, шо є сферою вивчення в більшій частині природознавчих наук. Водночас можна виокремити та вивчити ті чинники, які безпосередньо впливають на сферу інтересів юридичної науки, а саме кримінального права. Серед таких чинників авторка у своїй статті називає внутрішні, до яких відносить: тип і форму держави; правонаступниитво; рецепцію; стан економічних, політичних та інших сочіальних відносин; зміну иіннісних орієнтирів суспільства; стан розвитку правової науки, освіти, нормотворчої техніки та юридичної практики; зовнішні: статус та авторитет держави в міжнародній спільноті; європейський вектор; прочес глобалізачї, який зі свого боку передбачає стимульований гуманітарним складником процес інтерначіоналізачї начіональних правових систем, активізачію прочесів рещепиї, гармонізащї, уніфікащії та стандартизачї законодавства різних держав, а також визнання національною правовою системою гармонізованих $і$ уніфікованих правових принципів і норм, а також правових доктрин і теорій. До ситуативних чинників авторка відносить: тимчасові загрози життю та здоров'ю людей, які можуть мати місие протягом більш-менш тривалого часу, поширюватися поза межі країни (наприклад, пандемія захворювання, загроза стихійного лиха тощо); корупиійні ризики (останні можуть бути пов'язані, наприклад, із перебуванням на ключових посадах держави безпосередньо в органах виконавчої або законодавчої влади осіб, які мають стосунок до корупиійних схем, корупиійних скандалів тошо); тиск із боку непровладних міжнародних корпорачій або окремих осіб, які, переслідуючи свої власні інтереси через громадські організації (иляхом спонсорування, здійснення благодійницької діяльності, наприклад) намагаються домогтися прийняття державними органами «необхідних» рішень тощо.

Ключові слова: система принципів кримінального права, внутрішні чинники, зовнішні чинники, ситуативні чинники.

Постановка проблеми. На наше переконання, сьогодні істотним і нагальним для кримінально-правової доктрини, а також практики застосування законодавства про кримінальну відповідальність є визначення чинників, які так чи інакше впливають на становлення та формування принципів кримінального права. У своїх попередніх дослідженнях ми наголошували, що в процесі історичного розвитку всієї сукупності суспільних відносин з'являються певні закономірності, які з часом можна назвати принципами. Такі положення можуть стосуватись як усієї сукупності суспільних відносин, так і окремих ï̈ аспектів. 3 усіх принципів, властивих тим чи іншим явищам, особливо велике значення мають правові принципи, тому що тільки право є єдиним базовим загальносоціальним, універсальним, інтегративним, обов'язковим, охоронюваним державою, найсправедливішим і таким, що постійно вдосконалюється, регулятором усіх життєво важливих суспільних відносин.

Однак у цьому випадку нас найбільшою мірою цікавить питання чинників, які впливають на вирішення поставленого питання. Окрім політичних, економічних чинників, які в більшій частині висвітлені в науковій літературі, ми торкнемось так званих сuтуативних чинників, роль і значення яких сьогодні суттєво підвищилась. Саме тому ми вирішили дослідити природу та сутність 
чинників, які вже були названі в науковій літературі, так і нових, які ми назвали ситуативними. На нашу думку, виявлені чинники ще не мали чітких обрисів і безпосередньо не вивчались науковцями.

Необхідно також зазначити, що дослідження чинників, які здійснюють безпосередній вплив на формування системи принципів кримінального права відіграє важливу роль й у визначенні напрямів розвитку сучасного законодавства про кримінальну відповідальність, а також більшою мірою може посприяти запобіганню помилкам і розвиткові у хибному напрямі.

Аналіз останніх досліджень і публікацій. Проблемі з'ясування суті поставленого нами питання присвячували свої роботи такі вітчизняні та зарубіжні вчені, як: П.С. Берзін, В.О. Гацелюк, І.М. Гнатів, О.П. Горох, О.О. Дудоров, Ю.Л. Дятлова, М.А. Залигіна, С.Г. Келіна, В.Н. Кудрявцев, М.А. Малигіна, М.В. Мазур, В.В. Мальцев, В.О. Навроцький, А.Е. Скакун, Л.Ю. Тимофєєва, В.І. Тютюгін, В.Д. Філімонов, Д.Ю. Фісенко, Є.С. Чередніченко, К.В. Шундиков та багато інших.

Водночас вказані автори не досліджували поставлене нами питання 3 погляду сучасного стану справ з огляду на теперішні виклики та проблеми. Переважно згадані науковці вивчали природу та основні ознаки загальноправових принципів кримінального права. Тому є потреба вивчити поставлене нами питання більш детально.

Наприклад, П.С. Берзін у своїх роботах здійснював систематизацію принципів та надав їм стислу характеристику. Також частково досліджував історію походження принципів кримінального права. О.О. Дудоров та М.В. Мазур здійснювали порівняльну характеристику окремих злочинів і вивчали їхню природу. Д.Ю. Фісенко досліджувала спеціальні принципи кримінального права та надавала їм характеристику. С.Г. Келіна та В.Н. Кудрявцев грунтовно вивчали питання загальноправових і спеціальних принципів кримінального права, але за радянських часів тощо.

Метою статті $€$ встановлення основних чинників, які можуть мати безпосередні важелі впливу на формування як правової системи загалом, так і основоположних начал кримінального права (принципів) зокрема.

Виклад основного матеріалу. Загалом чинники формування й розвитку законодавства та правової системи - це соціально значущі обставини, які визначають необхідність створення нормативно-правових актів, формування інститутів і галузей законодавства, їхній зміст, корекцію чинних актів відповідно до завдань суспільства [1].

Із згаданого визначення випливає, що досліджуване нами явище це передусім «соціально значущі обставини». Отже, ми насамперед з'ясуємо, що вони собою являють.

Отже, такі чинники зумовлені політичними подіями, економікою, культурними традиціями, менталітетом, громадською думкою, впливом міжнародних організацій і міжнародних стандартів і визначають: зміст і форму законодавства, його внутрішню узгодженість і структуру, юридичну силу, час створення та ефективність нормативно-правових актів. Вони насамперед поділяються на внутрішні та зовнішні. Ми зі свого боку також виокремили ситуативні чинники, які мають тимчасовий характер, але сприймаються законодавцем більш жваво й активно, аніж інші чинники

У науковій і навчальній літературі до внутрішніх чинників відносять такі: тип і форму держави; правонаступництво; рецепцію; стан економічних, політичних та інших соціальних відносин; зміну ціннісних орієнтирів суспільства; стан розвитку правової науки, освіти, нормотворчої техніки та юридичної практики; до зовнішніх зазвичай відносять: статус та авторитет держави в міжнародній спільноті; європейський вектор; процес глобалізації.

Спочатку розглянемо природу та сутність внутрішніх чинників.

Tun $i$ форма держави. Вказані чинники визначають структуру і зміст законодавства, його пріоритети щодо регулювання приватної і публічної сфер. Наприклад, створення держави у формі федерації породжує дуальну систему її законодавства 3 його поділом на федеральне законодавство і законодавство суб'єктів федерації. Що стосується такої галузі законодавства, як кримінальне право, то воно зазвичай належить до публічної сфери незалежно від типу та форми держави.

Правонаступниитво як чинник передбачає зберігання і перенесення в законодавство норм та інститутів, які існували на попередньому історичному етапі розвитку держави. Воно підтримує і зберігає національні правові традиції, засновані на використанні звичаїв, норм моралі. Така ситуація відбулась на початку 90-х років, коли Україна здобула свою незалежність, відокремилась від інших союзних республік і союзного законодавства. Тобто на той момент в Україні не було власної законодавчої бази і не було можливості відразу створити власну законодавчу базу, тому й було прийнято відповідній нормативний документ, який узаконив правонаступництво законодавства колишнього СРСР [2] 
Реиепиія як запозичення норм та інститутів права інших держав (наприклад, у Розділі XVII «Злочини у сфері службової діяльності та професійної діяльності, пов'язаної із наданням публічних послуг» 3'явилася низка норм, якими передбачено відповідальність за такі суспільно небезпечні діяння, як ст. 368 «Прийняття пропозиції, обіцянки або одержання неправомірної вигоди службовою особою», ст. 368-3 «Підкуп службової особи юридичної особи приватного права незалежно від організаційно-правової форми» та інші, що стало результатом проведення євроінтеграційних процесів у законодавстві про кримінальну відповідальність) [3]. Завдяки цьому злочинами було визнано такі діяння, які раніше злочинами українським законодавцем не визнавались.

Стан економічних, політичних та інших сочіальних відносин спричиняє появу нових галузей та інститутів законодавства, зокрема комплексних (підприємницьке, комерційне, інформаційне), оновлення законодавства тобто доповнення або скасування нормативноправових актів (наприклад, ринкові відносини зумовлюють суттєве оновлення законодавства в економічній сфері, реформування ринку праці та інші). Звичайно, вказані процеси залишають свої відбитки й на галузі законодавства про кримінальну відповідальність.

Зміна иіннісних орієнтирів суспільства зокрема гуманітарних, культурологічних ідеологічних. Така зміна може бути викликана, наприклад, активними євроінтеграційними процесами, які відбуваються сьогодні в Україні. Так, саме завдяки названим процесам у чинному законодавстві України з'явились такі принципи, як принцип юридичної (правової) визначеності, принцип верховенства права тощо. Заради справедливості зазначимо, що хоча принцип верховенства права й існував у вітчизняному законодавстві ще за радянських часів, водночас сьогодні він набув іншого, так би мовити, європейського значення.

Стан розвитку правової науки, освіти нормотворчої техніки та юридичної практики. Саме стан розвитку названих сфер відносин визначає можливість сприйняття тих чи інших новітніх передових ідей, які з'являються в світі, а також визначає й рівень правосвідомості населення держави. Задля забезпечення розвитку названої сфери суспільних відносин велике значення має також і матеріально-технічне забезпечення останніх.

Велике значення мають також й зовнішні чинники. Серед таких ми назвали: статус та авторитет держави в міжнародній спільноті, ӥ участь у міжнародних організачіях Перший із названих чинників визначається своєчасним дотриманням держави взятих на себе міжнародних зобов'язань, станом відносин із сусідніми та іншими державами, сферами таких взаємовідносин, їхньою численністю тощо. Зокрема, Україна обрала європейський вектор розвитку, дотримується міжнародно-правових стандартів у сфері прав людини, інтегрується у світові економічні, політичні, гуманітарні та інші процеси. Відповідно, міжнародне право суттєво впливає на законодавство України. Такий вплив може бути як позитивним, так і негативним. Наприклад, введення в систему принципів кримінального права такого принципу, як принцип юридичної (правової) визначеності, на нашу думку, позитивно впливатиме на вдосконалення та подальший розвиток законодавства про кримінальну відповідальність. Водночас знову ж таки, на нашу думку, намагання окремих суб'єктів законодавчої ініціативи змінити поняття суб'єкта злочину, додавши до фізичної особи ще й юридичну, похитне, навіть виключить із системи принципів кримінального права такий важливий усталений у вітчизняному законодавстві принцип, як принцип особистої відповідальності.

Участь держави у міжнародних організаціях являє собою можливість, а подекуди й право певної держави впливати або брати участь у розв'язанні конфліктних ситуацій, які можуть виникати між учасниками міжнародних спільнот, отримувати від інших учасників допомогу різного роду та консультації тощо.

На змісті законодавства та сутності тієї чи іншої правової системи також позначаються процеси глобалізації, зокрема правової. Під правовою глобалізацією розуміють стимульований гуманітарним складником процес інтернаціоналізації національних правових систем, активізацію процесів рецепції, гармонізації, уніфікації та стандартизації законодавства різних держав.

Правова глобалізаиія передбачає, зокрема, визнання національною правовою системою гармонізованих і уніфікованих правових принципів і норм, а також правових доктрин і теорій. Нині можна зазначити, що саме в процесі глобалізації романо-германьска та англосаксонська правові системи поступово втрачають свою специфічність та активно інтегруються одна в одну. Зокрема, сьогодні можна з впевненістю стверджувати, що завдяки згаданому вище явищу в жодній країні в чистому вигляді жодна з перелічених правових систем вже не існує.

До ситуативних чинників, на наше переконання, необхідно віднести такі: тимчасові загрози життю та здоров'ю людей, які можуть мати місце протягом більш-менш тривалого часу, можуть поширюватися поза межі країни (наприклад, пандемія захворю- 
вання, загроза стихійного лиха тощо); корупиійні ризики (останні можуть бути пов'язані, наприклад, із перебуванням на ключових посадах держави безпосередньо в органах виконавчої або законодавчої влади осіб, які мають стосунок до корупційних схем, корупційних скандалів тощо); тиск із боку непровладних (комериійних) міжнародних корпорачій або окремих осіб, які, переслідуючи свої власні інтереси, через громадські організації (шляхом спонсорування, наприклад) намагаються домогтися прийняття державними органами «необхідних» або «зручних» для них рішень тощо.

Усі перелічені чинники мають тимчасовий характер, однак мають у своєму розпорядженні важелі, які більш оперативно можуть впливати на формування не тільки окремих норм законодавства про кримінальну відповідальність, а й брати активну участь у формуванні самої системи ії основоположних начал (принципів).

Також зазначимо, що саме останні чинники можуть негативно вплинути на формування системи принципів кримінального права, адже ситуативний характер останніх зазвичай негативно впливає на якість нормативно-правових актів і правової системи загалом. Адже закони зазвичай розраховані на тривалий, а не ситуативний строк свого використання.

\section{Висновки}

Отже, чинники, які впливають на формування системи права загалом і принци- пів кримінального права зокрема, визначені в науковій літературі доволі повно й мають свою власну систему. Згадана система $€$ відкритою, що передбачає можливість долучення в неї нових чинників. Водночас компонування останніх може бути різним, тобто акценти можуть бути розставлені по-різному. Отже, з огляду на виклики сьогодення, наукою кримінального права повинно більш ретельно та грунтовно вивчатись питання щодо виявлення та вивчення механізму впливу чинників на формування та становлення системи принципів кримінального права. Під час дослідження нами вивчались зовнішні та внутрішні чинники, які тією чи іншою мірою впливають на подальший розвиток законодавства про кримінальну відповідальність. А також встановлені нові чинники, які переважно мають ситуативний характер, але можуть у деяких випадках більш оперативно та суттєво впливати на формування як закону про кримінальну відповідальність, так і всієї системи принципів кримінального права.

\section{Список використаних джерел:}

1. URL: https://pidruchniki.com/70666/ pravo/chinniki_formuvannya_rozvitku_sistemi_ zakonodavstva.

2. Закон України «Про правонаступництво України» від 12 вересня 1991 p. URL: https:// zakon.rada.gov.ua/laws/show/1543-12.

3. Кримінальний кодекс України від 5 квітня 2001 p. URL: https://zakon.rada.gov.ua/laws/ show/2341-14.

Olena Oliinyk. The characteristics of external and internal factors that in one way or another affect the formation and formation of the principles of criminal law

The article deals with the identification of factors that in one way or another affect the formation and formation of the principles of criminal law in the aspect of the formation of the legal system as a whole. The author of the article refers to the experience of today, which clearly demonstrated that humanity, in the event of a critical situation that threatens the lives of many people, is primarily guided by their instincts, which are the field of study in most of the natural sciences. At the same time, it is possible to distinguish and study those factors that directly affect the sphere of interest of legal science, namely criminal law. Among such factors, the author in her article refers to internal ones, which include: the type and form of the state; succession; reception; state of economic, political and other social relations; change of values of society; state of development of legal science, education, rulemaking technique and legal practice; external: status and authority of the state in the international community; European vector; the process of globalization, which in turn provides for the humanitarian component stimulated by the process of internationalization of national legal systems, intensification of the processes of reception, harmonization, unification and standardization of the lawes of different states, as well as the recognition by the national legal system of harmonized and unified legal principles and norms, as well as the legal doctrines. Situational factors include: temporary threats to the life and health of people, which may occur for more or less a long time, spread outside the country (e.g., a pandemic, a threat of a natural disaster, etc.); corruption risks (the latter may be related, for example, to the presence in key positions of the state directly by bodies of executive or legislative power of persons related to corruption schemes, corruption scandals, etc.); pressure from non-governmental international corporations or individuals who, in pursuit of their own interests through public organizations (through sponsorship, for example), seek to achieve "necessary" decisions by public authorities and the like.

Key words: system of principles of criminal law, internal factors, external factors, situational factors. 